\title{
Current overview and potential applications of the soil ecosystem services approach in Brazil
}

\author{
Rachel Bardy Prado(1), Elaine Cristina Cardoso Fidalgo(1), Joyce Maria Guimarães Monteiro(1), \\ Azeneth Eufrausino Schuler(1), Fabiane Machado Vezzani(2), Junior Ruiz Garcia( ${ }^{(3)}$, \\ Aline Pacobayba de Oliveira(1), João Herbert Moreira Viana ${ }^{(4)}$, Bernadete da Conceição Carvalho Gomes Pedreira(1), \\ leda de Carvalho Mendes ${ }^{(5)}$, Adriana Reatto(6), Lucília Maria Parron ${ }^{(7)}$, Eliane de Paula Clemente ${ }^{(1)}$, \\ Guilherme Kangussu Donagemma ${ }^{(1)}$, Ana Paula Dias Turetta ${ }^{(1)}$ and Margareth Simões ${ }^{(1)}$
}

\begin{abstract}
(1)Embrapa Solos, Rua Jardim Botânico, no 1.024, Jardim Botânico, CEP22460-000 Rio de Janeiro, RJ, Brazil. E-mail: rachel.prado@embrapa.br, elaine.fidalgo@embrapa.br,joyce.monteiro@embrapa.br,azeneth.schuler@embrapa.br,aline.oliveira@embrapa.br,bernadete.pedreira@embrapa.br, eliane.clemente@embrapa.br, guilherme.donagemma@embrapa.br, ana.turetta@embrapa.br, margareth.simoes@embrapa.br(2)Universidade Federal do Paraná (UFPR), Departamento de Solos e Engenharia Agrícola, Rua dos Funcionários, № 1540, Juvevê, CEP 80035-050 Curitiba, PR, Brazil. E-mail: vezzani@ufpr.br ${ }^{(3)}$ UFPR, Departamento de Economia, Avenida Prefeito Lothário Meissner, no 632, Térreo, Jardim Botânico, CEP 80210-170 Curitiba, PR, Brazil. E-mail: jrgarcia1989@gmail.com ${ }^{(4)}$ Embrapa Milho e Sorgo, Rodovia MG 424, Km 45, CEP 35701-970 Sete Lagoas, MG, Brazil. E-mail: joao.herbert@embrapa.br ${ }^{(5)}$ Embrapa Cerrados, BR 020, Km 18, CEP $73310-970$ Planaltina, DF, Brazil. E-mail: ieda.mendes@embrapa.br ${ }^{(6)}$ Embrapa Informação Tecnológica, Parque Estação Biológica, W3 Norte (Final), Caixa Postal 040315, CEP 70770-901 Brasília, DF, Brazil. E-mail: adriana.reatto@embrapa.br ${ }^{(7)}$ Embrapa Florestas, Estrada da Ribeira, Km 111, Caixa Postal 319, CEP 83411-000 Colombo, PR, Brazil. E-mail: lucilia.parron@embrapa.br
\end{abstract}

Abstract - Human pressure on ecosystems has undesirable impacts on human well-being. After the Millennium Project, much interdisciplinary research has been developed worldwide aiming to understand these impacts on ecosystem flows and processes, and to learn about the costs and the benefits of ecosystem services for production. Soil provides many ecosystem services, since its multi-functionality is the basis for food production, water filtration, nutrient cycling, and other goods essential to life. This article presents the main concepts and classifications of soil ecosystem services and of its functions; the indicators and the methods for assessment, modeling, and valuation of ecosystem services; some recent applications to assess and evaluate impacts of agricultural management practices on soil ecosystem services; as well as challenges and opportunities for research and for development of public policies related to agro-environmental sustainability in Brazil. Although the role of soil in supplying ecosystem services is yet undervalued, scientists are gradually recognizing soil processes and functions as fundamental to assess ecosystem services and the effects of land use and management on them. Interdisciplinary approaches to integrate science and public policies are necessary to build governance based on ecosystem services.

Index terms: economic valuation, environmental services, soil function, soil indicators, soil management, public policy, soil quality.

\section{Panorama atual e potencial de aplicação da abordagem dos serviços ecossistêmicos do solo no Brasil}

Resumo - A pressão humana sobre os serviços ecossistêmicos tem resultado em impactos indesejáveis sobre o bem-estar humano. Com o Projeto Millennium, várias pesquisas interdisciplinares têm sido desenvolvidas em todo o mundo com o objetivo de entender esses impactos sobre os fluxos e os processos dos ecossistemas e internalizar os custos e os benefícios dos serviços ecossistêmicos para a produção. O solo fornece muitos serviços ecossistêmicos, uma vez que sua multifuncionalidade é a base para a produção de alimentos, filtração de água, ciclagem de nutrientes e outros bens essenciais à vida. Este artigo apresenta os principais conceitos e classificações dos serviços ecossistêmicos do solo e de suas funções; os indicadores e os métodos de avaliação, modelagem e valoração dos serviços ecossistêmicos; algumas aplicações recentes para avaliar impactos de práticas de manejo agrícola sobre os serviços ecossistêmicos do solo; bem como os desafios e as oportunidades para a pesquisa e para o desenvolvimento de políticas públicas relacionadas à sustentabilidade agroambiental no Brasil. Apesar de o papel do solo para prestação de serviços ecossistêmicos ainda ser subestimado, os cientistas têm gradualmente reconhecido os processos e as funções do solo como fundamentais para avaliar os serviços ecossistêmicos e os efeitos do uso e manejo da terra sobre eles. Abordagens interdisciplinares que integrem ciência e políticas públicas são necessárias para construir uma governança com base em serviços ecossistêmicos.

Termos para indexação: valoração econômica, serviços ambientais, função do solo, indicadores de solo, manejo do solo, política pública, qualidade do solo. 


\section{Introduction}

Over the past 50 years, humans have changed ecosystems more rapidly and extensively than at any other period of time in history (Millennium Ecosystem Assessment, 2005). The conversion of forests into agricultural lands has exerted strong pressure on aquatic and terrestrial ecosystems. Unsuited management practices and indiscriminate use of agrochemicals have led to soil degradation, water pollution, reduction of productivity rates and biodiversity losses, in addition to impacts related to climate change, such as greenhouse gas (GHG) emissions. These damages have compromised their capacity to supply ecosystem services (ES), defined as "the benefits supplied to human societies by natural ecosystems" (Daily et al., 1997).

A big challenge to recover ecosystems and guarantee agriculture sustainability is to design and adopt changes in current agricultural and forestry production systems in order to make them provide a variety of ecosystem services. To reach these goals, research aimed at understanding ecosystem dynamics and multifunctionality in a landscape context is essential to assess impacts of changes in both natural ecosystems and agricultural systems on human wellbeing (Barkmann et al., 2004; Bradshaw \& Sykes, 2014).

The application of ES research results in decisionmaking can provide solutions for real problems faced by society and ecosystems (Daily et al., 2009). The ecosystem service approach has evolved from concepts proposed in the late 1960s and throughout 1970 s, which highlighted the societal value of nature's functions (Hermann et al., 2011). Since the release of the Millennium Ecosystem Assessment (2005), publications on ecosystem services have increased exponentially, focusing on assessment, classification, quantification, mapping, modelling, and valuation of ecosystem services in order to integrate the concept into decision-making.

This paper aims to present fundamental concepts and an overview of methods and applications of soil ecosystem services, as well as their usefulness for decision-making. In this context, the ecosystem service concept emerged from the work of ecologists and economists who were concerned with environmental degradation, and expanded across areas of knowledge and countries, drawing the attention of various stakeholders and researchers, eventually moving to specific questions on methods and applications (Chaudhary et al., 2015). This scenario requires conceptual frameworks and standardized procedures, as well as transparency and clearness for communication aimed at overcoming cultural barriers and those of different areas of knowledge (Nicholson et al., 2009). Therefore, following this introduction, the second session presents the main concepts of soil ecosystem services and their functions. The Millennium Ecosystem Assessment (2005) conceptual framework has been the most influential basis on which a variety of specific classification frameworks has been developed, and this paper presents a classification designed specifically for soil ES based on acknowledged ES frameworks.

Methods for assessing, measuring and quantifying soil ecosystem services are addressed in the third session, which presents soil ES approaches from the soil quality concept and indicators to ecosystem process-based models. As soil is a cognitive integrator of water security, agricultural production, energy, climate and biodiversity (McBratney et al., 2014), all the impacts on soil will have indirect impacts on other ES and human welfare. Thus, developing models and metrics that represent causality relationships among environmental, societal and economical processes is a necessary task to provide comprehensive information for decision-making. Therefore, the fourth session highlights valuation methods, which have showed a major importance to policy-makers' acknowledgement of costs and benefits associated with ecosystem services.

The fifth session points out newly developed applications of methods to assess soil ES and related impacts of agricultural management, with studies carried out in different regions of the world, focusing on different spatial scales and objectives, from local farming systems evaluation to national agricultural policy assessment. Finally, in the last session, this study presents challenges and opportunities for research and policy-making related to agro-environmental sustainability in Brazil. The concepts of ES, as well as the complementary concept of "environmental services", have gradually been adopted in Brazil, both by the scientific community and decision-makers. The environmental services are "the environmental benefits from selected interventions by society which influence ecosystem dynamics" (Muradian et al., 2010). In other 
words, they are generated from conservationist actions carried out by society. Despite the growing use of these concepts, the interdisciplinary, systemic and dynamic ES approach must be improved to provide information to decision-makers. For that, comprehensive tools on how policy-induced soil management practices and land use changes affect ecosystem services and consecutive benefits to society are essential to subsidize consistent decision-making.

Therefore, the purpose of this review is to provide subsidies and motivation for research on soil ecosystem service approaches, in order to generate integrated results and applications to policy-makers, in Brazil, aiming at agro-environmental sustainability.

\section{Soil ecosystem services}

Although the role of soil and its functions for ES and society have been historically undervalued (Bouma, 2005; Robinson et al., 2014), the interest in soil systems has grown. In recent decades, several soil scientists have referenced multiple functions and services of soil, considering it a complex system intrinsically related to human security, environmental integrity, and to economic aspects (Blum, 2005; Haygarth \& Ritz, 2009; Robinson et al., 2014).

Over the last two decades, different categories of ES have been proposed, aiming at a better understanding of ES (Costanza et al., 1997; De Groot et al., 2002; Millennium Ecosystem Assessment, 2005; HainesYoung \& Potschin, 2010; Kandziora et al., 2013). There is no consensus regarding the establishment of a single classification model. Haines-Young \& Potcshin (2010) stressed that it is unlikely that a list of simple and generic classification of the services could encompass the diversity of ecosystems and regions. It is important to add the wide range of perceptions on ES - and the demands on them from society - to the variety of local and regional characteristics of the environment. Therefore, our effort to list and classify ES in different categories must be regarded as a general guide.

Several authors mentioned that ecosystem frameworks generally failed to show the role of soils as ES suppliers. Despite the relevance of the Millennium Ecosystem Assessment (2005) framework, there is a sense that this approach has restricted soil to "supporting services" (Robinson et al., 2012; Dominati et al., 2014a). The reasons pointed for this restricted view are the difficulty in quantifying ES adequately, the necessity of standardized definitions, and the lack of operational tools that can translate theoretical frameworks and represent dynamic processes. Taking these into account, specific frameworks and classifications of soil functions have been proposed by Planning for Sustainable Use of Land Resources (1995), Blum (2005), European Commission (2006), Haygarth \& Ritz (2009), and Dominati et al. (2010). Table 1 shows the main ES derived from the several functions performed by the soil.

The approach to soil ecosystem functions has been developed from discussions on soil quality since the 1990s, when the focus was on building criteria to assess and evaluate soil management practices, which sought sustainability of agricultural management. In 1997, as a deliberation of SSSA (Soil Science Society of America), the Committee on Soil Quality presented the following concept of soil quality: "the capacity of a specific kind of soil to function, within natural or managed ecosystem boundaries, sustaining plant and animal productivity, maintaining or enhancing water and air quality, and supporting human health and habitation" (Karlen et al., 1997). Thus, besides the importance to food production, the soil quality concept is linked to the ecosystem's global functioning.

The great contribution of the evolved soil quality concept to the knowledge of soils is perhaps the integrated vision of them, which has made common soil assessment grounded on its processes and functions. In this sense, Vezzani \& Mielniczuk (2011) highlight the increasing need to assess soil quality addressing soil as a complex system, with innumerous relations among the ecosystems and soil system components.

Soil functions are interrelated, meaning that each function depends on another to perform its role, as depicted in Figure 1. This figure, of course, does not encompass all relations; rather, it shows the dynamics between them and the whole functioning of soil in the ecosystem. The comprehension of this dynamics allows soil functions to be considered in the assessment and quantification of ES. Soil system works as a buffering/ reactive/controlling interface, covering most of land surface, being able to be changed to some extend by the human action.

The National Research Council (2001) presented the "critical zone" concept as the dynamic interface between fluid envelopes and solid materials, regulated

Pesq. agropec. bras., Brasília, v.51, n.9, p.1021-1038, set. 2016 DOI: $10.1590 / \mathrm{S} 0100-204 \mathrm{X} 2016000900002$ 
Table 1. Soil functions and ecosystem services.

\begin{tabular}{|c|c|c|}
\hline Soil function & Service & Ecosystem service \\
\hline Support for terrestrial vegetation & Support & Primary production \\
\hline Soil formation processes & Support & Soil formation and renewal \\
\hline Storage, cycling, processing of nutrients and delivery to plants & Support & Nutrient cycling \\
\hline $\begin{array}{l}\text { Supporting structures for human occupation and activities (for } \\
\text { example: housing, industry, infrastructure) }\end{array}$ & Support & Platform \\
\hline $\begin{array}{l}\text { Habitat for resident and transient populations (a vital } \\
\text { component for terrestrial habitats) }\end{array}$ & Provision & Refuge \\
\hline Water retention and supply in the landscape & Provision & Water storage \\
\hline Provision of plant growth and production & Provision & Supply of food, fibers, fuels and wood (biomaterials) \\
\hline Provision of source materials & Provision & Supply of raw materials of mineral origin \\
\hline Source of unique biological materials and products (soil biota) & Provision & Biodiversity and genetic resources \\
\hline $\begin{array}{l}\text { Population regulation (soil biota) to control pests, pathogens } \\
\text { and diseases }\end{array}$ & Regulation & Control of potential pests and pathogens \\
\hline Disposal and decomposition of residues and pollutants & Regulation & Recycling and remediation actions \\
\hline Filtration and buffering of water & Regulation & Water quality regulation \\
\hline $\begin{array}{l}\text { Regulation of hydrological flows, buffering and moderation of } \\
\text { hydrological cycle }\end{array}$ & Regulation & Water supply regulation, and flood and draught control \\
\hline $\begin{array}{l}\text { Carbon sequestration and accumulation, regulation of the } \\
\text { atmospheric chemical composition and climate processes }\end{array}$ & Regulation & Regulation of atmospheric GHG and climate regulation \\
\hline Sediment retention & Regulation & Erosion control \\
\hline Support for recreational activities & Cultural & Recreation \\
\hline Support for non-commercial activities & Cultural & $\begin{array}{l}\text { Development of cognitive, aesthetical, educational, } \\
\text { spiritual and scientific experiences and activities }\end{array}$ \\
\hline $\begin{array}{l}\text { Holds archaeological record of terrestrial occupancy and } \\
\text { civilizations }\end{array}$ & Cultural & Historic and cultural heritage \\
\hline
\end{tabular}

Source: Adapted from Barrios (2007), Haygarth \& Ritz (2009), and Dominati et al. (2010).

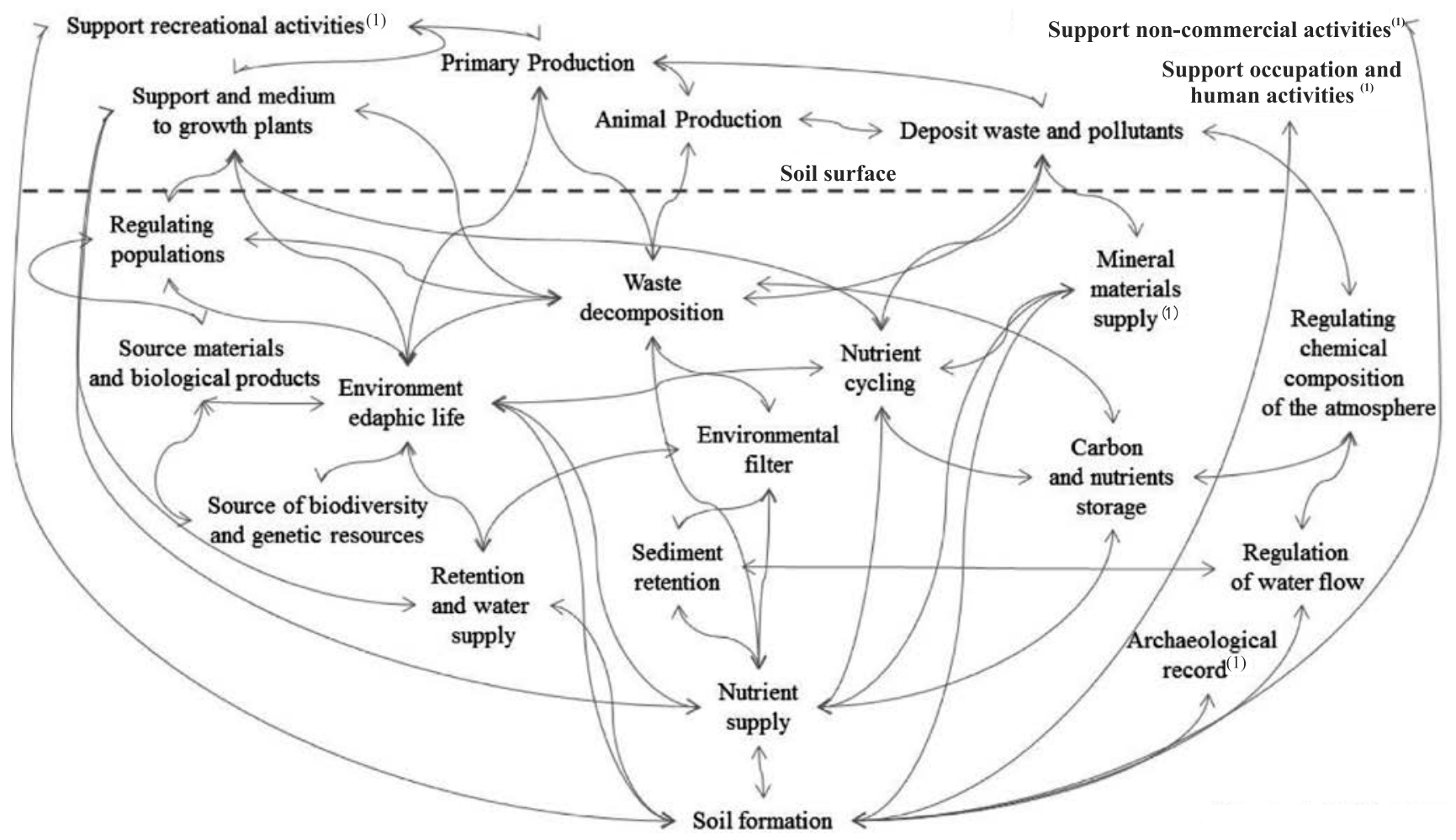

Figure 1. The soil ecosystem functions and their interrelations. ${ }^{(1)}$ Non ecological functions. 
by all biotic and abiotic processes that control the fluxes of mass and energy. As pointed by Field et al. (2015), the supply of ecosystem goods and services is controlled by the processes in this zone, including pedogenesis, hydrologic fluxes and landscape morphogenesis. Soil also plays a critical role in ecological processes related to the primary production in land ecosystems (Jenny, 1961).

The hydro-physical characteristics of the soils pose the limits to plant growth, the range of biodiversity that can live there, and affect the use of the soils for human purposes, especially agriculture (Power, 2010; Field et al., 2015). They also affect water and gas fluxes and, therefore, recharge of aquifers, runoff, and erosion.

Soil, with its complex patterns of pore/void system, is one of the most challenging interface systems to study and model, both in space and time. These and other soil patterns change over time and are very sensitive to management. So, to understand the role of soil as ES supplier, it is necessary not only to identify and classify soil ES, but also to adequately evaluate, monitor, and quantify such ES. While classifying soil ES demands a better conceptual framework of soil functions, quantifying soil ES requires the development of approaches considering soil processes, stocks and fluxes, and their relations with other ecosystem components, such as water, atmosphere and biological systems.

\section{From soil function indicators to integrated methods}

Advances in soil science to understand soil ES are needed, especially because soil services arise at very different scales, ranging from microns (habitat for microorganisms) to landscape (flood mitigation), and to the planet itself (air quality) (Dominati et al., 2010). Moreover, the relevance of soil ES approaches for soil conservation has been pointed out in recent studies (Lal, 2014; Dumanski, 2015). This session presents the use of soil function indicators to assess soil quality, the increasing development of integrated methods to evaluate ES, and how soil is considered in the latter.

Considering the complex relations between soil management and policies, researchers have stressed the challenge of developing fast and simple methods to assess soil quality and land use sustainability at local, regional, national, continental and global levels
(Velasquez et al., 2007; Rutgers et al., 2012; Year book 2012, 2012).

Doran \& Parkin (1994) proposed one of the first soil quality indexes, which was oriented to soil function assessment based on food quality (nutrition and security), water and air quality, crop production and protection against erosion. Since then, all the other indexes have been based on soil function assessment, and the studies have explored different aspects: biological indicators (Parisi et al., 2005); microbiological indicators (Monokrousos et al., 2006); physical-chemical indicators (Chen et al., 2006); organic matter (Shukla et al., 2006), qualitative analyses (Barrios et al., 2006); and landscape integrated analyses, modeling, and mapping (Mele \& Crowley, 2008).

Indicators contribute to understand the current state of the soil and to assess negative or positive impacts from land use and cover changes (Tóth et al., 2007; Pulleman et al., 2012), which may affect the provision of soil ES. Soil quality indicators proved to be important for designing management practices and techniques aimed at soil restoration, and for monitoring their suitability (Velasquez et al., 2007). However, considering the heterogeneity of edaphic and climate conditions, in addition to the environmental, social, political, and economic aspects that influence soil management, and therefore soil quality, an universal index has not proved to be feasible. Therefore, the scientific community has abandoned the idea of a single approach to assess soil quality, and soil function assessment at local and regional scale has grown.

The conceptual approach presented by Karlen \& Stott (1994) is supported by the latter perspective. They have proposed a soil quality index based on the selection of soil ecological functions, according to the interests of managers and technicians, such as soil water storage, degradation resistance, or support for plant growth. In this approach, each soil ecological function is weighed in order to consider its significance to the objective assessed. Currently, in order to establish weights to soil functions in different management contexts, several authors have used statistical analyses to correlate the soil attributes to those of farming systems, as well as the principal component analysis to assess selected soil functions (Velasquez et al., 2007; Paz-Kagan et al., 2014; Liu et al., 2015).

Pesq. agropec. bras., Brasília, v.51, n.9, p.1021-1038, set. 2016 DOI: 10.1590/S0100-204X2016000900002 
The large experience accumulated from studies on soil quality assessment has shown the high sensitivity of biological indicators to distinguish differences between several land uses and managements (Aziz et al., 2013; Rousseau et al., 2013; Paz-Kagan et al., 2014; Liu et al., 2015). Cardinale et al. (2012) highlight that biological attributes represent ecological processes that promote $\mathrm{ES}$, and the performance of soil ecosystem functions is a result of life-driven relations in the soil system. The use of soil quality indicators has evolved to functional and relational approaches which consider soil as a complex system. Nonetheless, effective understanding of the role played by soil on the provision of ES to society depends on integrated methodologies to assess, quantify, map, and valuate ES.

Willemen et al. (2015) pointed out that a wide variety of methods to assess and map ES has helped the field to progress and evolve in several directions and contexts. However, this diversity challenges the integration of ES information into policy-making, natural resource management, and "green accounting". One helpful initiative was the Mapping and Modelling (Ecosystem Services Partnership, 2016) working groups of the Ecosystem Service Partnership (ESP), which have provided information on tools, guidelines and standards to improve spatial and temporal dynamic analyses, mapping ES and modeling tools. Some reviews on ES mapping have also been published (Egoh et al., 2012; Martinéz-Harms \& Balvanera, 2012; Burkhard et al., 2013; Crossman et al., 2013; Peh et al., 2013; Willemen et al., 2015), in the face of the increasing importance of its role in conservation investments, land use planning, and development assessment. Addressing the problem of information integration, Crossman et al. (2013) proposed a standard blueprint to help organize these studies, and built it during the 5th ESP Conference in 2012. The blueprint consists of a preamble with metainformation about the study, and a table with attributes for studied services.

Martinéz-Harms \& Balvanera (2012) mentioned the general use of models based on the well-known causal relationships between environmental variables, followed by the extrapolation of ES values to the analyzed area using land-cover maps. They warned that the use of secondary data, frequently applied at broad scales, without validation techniques, could be misleading. Authors also urged for the development of methods to understand the social-ecological processes behind the supply of ES. Willemen et al. (2015) highlighted the best ES mapping practices to support decision-making. These mapping practices include robust modeling, measurement, and stakeholder-based methods to quantify ES supply, demand or flow, as well as measures of uncertainty and heterogeneity across spatial and temporal scales and resolutions.

Considering the variety of methods to assess, map, and model ES, this study presents some examples of tools to model ES in an integrated way (Table 2).

In general, tools do not focus specifically on soil ES, except MOSES, which aims at modelling them. Two other ES modelling methods consider soil functions explicitly: InVEST, which considers soil functions affecting other ES, e.g., sediment retention, which quantifies soil loss and retention and values the avoided cost of water treatment or dredging; and SPASMO, where the generation of soil property dynamics constitutes the first step in the quantification of soil services.

There are also some tools, used to assess and quantify ES, based on mass-balanced models that simulate surface processes. The LPJmL (Lund-Potsdam-Jena Managed Land) simulates vegetation composition and distribution, as well as stocks and land-atmosphere exchange flows of carbon and water, both for natural and agricultural ecosystems (Bondeau et al., 2007); and JULES (Joint UK Land Environment Simulator) assesses the impact of modifying a particular process on the ecosystem by modelling the interaction of several surface processes, such as surface energy balance, the hydrological cycle, the carbon cycle, and the vegetation dynamics (Best et al., 2011).

Published methods have shown the relevance of integrated approaches in terms of scales and multiple services. These innovative approaches, following the example of the first three tools mentioned above, should be able to assess soil processes that provide multiple ES, and to describe and quantify impacts of soil management on these processes.

\section{Valuation of soil ecosystem services}

Most ES, having characteristics of public goods, are not traded in conventional markets, and they have neither prices nor monetary values (De Groot et al., 2012; Costanza et al., 2014). Thus, they have not been considered by economic agents in their decision- 
making, which has led to ecosystem degradation. However, there have been attempts to express ES through economic valuation, aimed at representing their importance to human well-being (Egoh et al., 2012; Costanza et al., 2012, 2014).

Several authors have mentioned that ES have different values in addition to the economic one, such as social, cultural, and ecological values; and not all of them can be translated into monetary units (Costanza \& Kubiszewski, 2012; De Groot et al., 2012; Hernández-Morcillo et al., 2013; Costanza et al., 2014). The economic valuation has prevailed due to its potential to inform different audiences, especially for decision-making in the capitalist system (Costanza et al., 2014).

Like other natural resources, soil also provides a set of ES, which have characteristics of public goods (Millennium Ecosystem Assessment, 2005; Dominati et al., 2010). Valuing this asset could reveal the importance of the ES provided by soil and the influence of the use and management practices on those ES.
The valuation process consists of two steps: i) biophysical assessment and measurement of ES; and ii) translating biophysical results into monetary values. For the second step, there is a wide range of techniques and methods (Figure 2) (Romeiro \& Maia, 2011; De Groot et al., 2012; Costanza et al., 2014).

Indirect methods aim at estimating ES values based on a production function, which relates the ES to "substitute goods", or even to other natural or manmade resources available on the market - observable market prices are considered "shadow prices". As these prices are determined by "exchange value" or "use value", the ES values tend to be underestimated (Ortiz, 2003; Motta, 2006; An introductory..., 2007). Direct valuation methods (Figure 2) try to overcome this limitation by estimating non-economic ES values based on direct consultation to stakeholders (Ortiz, 2003; Romeiro \& Maia, 2011).

Although soil is responsible for the provision of many ES, assessment studies have generally focused on the assessment of the nutrient loss due to soil

Table 2. Examples of tools to model and assess ecosystem services.

\begin{tabular}{|c|c|}
\hline Tool and main reference & Description \\
\hline $\begin{array}{l}\text { Toolkit for Ecosystem Service at Site-based Assessment } \\
\text { (TESSA) } \\
\text { (Peh et al., 2013) }\end{array}$ & $\begin{array}{l}\text { Practical suite of tools for measuring and monitoring ecosystem services at a site scale, with } \\
\text { low cost. } \\
\text { It helps users identify which ES should be assessed, which data are needed to measure them, } \\
\text { which methods or sources might be used in different contexts, and how the results can then } \\
\text { be communicated }\end{array}$ \\
\hline $\begin{array}{l}\text { The Integrated Valuation of Ecosystem Services and } \\
\text { Tradeoffs (InVEST) } \\
\text { (Natural Capital Project, 2015) }\end{array}$ & $\begin{array}{l}\text { A suite of software models used to map and value the goods and services from nature. } \\
\text { The models are based on production functions that define how an ecosystem's structure and } \\
\text { function affect the flows and values of ecosystem services. The toolset currently includes } \\
\text { seventeen distinct models suited to terrestrial, freshwater, and marine ecosystems }\end{array}$ \\
\hline for Ecosystem Services (ARIES). & $\begin{array}{l}\text { An integrated ES modeling methodology and web application to assess the ES and illuminate } \\
\text { their values to help environmental decision-making. } \\
\text { The methodology is assisted by model integration technologies that allow assembly of } \\
\text { customized models from a growing model base }\end{array}$ \\
\hline $\begin{array}{l}\text { The Multiscale Integrated Models of Ecosystem Services } \\
\text { (MIMES). } \\
\text { (Boumans et al., 2015) }\end{array}$ & $\begin{array}{l}\text { A suite of models that evaluates land use changes and subsequent effects on ecosystem } \\
\text { services on global, regional and local levels, in the short and long term. } \\
\text { In MIMES, users formalize how materials are transformed between natural, human, built, } \\
\text { and social capitals. This information is synthesized within a system model to forecast ES and } \\
\text { human use dynamics under alternative scenarios }\end{array}$ \\
\hline $\begin{array}{l}\text { The Soil Plant Atmosphere System Model (SPASMO). } \\
\text { (Green et al., 2003) }\end{array}$ & $\begin{array}{l}\text { A process-based dynamic model that describes soil processes, plant growth and farm } \\
\text { management } \\
\text { SPASMO investigates the influence of management practices on plant growth and soil } \\
\text { properties and processes, enabling the evaluation of provision of soil services } \\
\text { Supporting and degradation processes make up the model core }\end{array}$ \\
\hline The Modelling Soil Ecosystem Services (MOSES) & $\begin{array}{l}\text { A process-based soil model that provides information about soil profile } \\
\text { MOSES targets soil ecosystem service-related functions, including carbon sequestration, } \\
\text { water buffering and biomass productivity. } \\
\text { Outputs are used to evaluate provision of soil ecosystem services }\end{array}$ \\
\hline $\begin{array}{l}\text { The nature value explorer } \\
\text { (Broekx et al., 2013) }\end{array}$ & $\begin{array}{l}\text { A web-based application for the estimation of two groups of final ecosystem services: cultural } \\
\text { services and regulating services. } \\
\text { The tool allows exploring the quantity and value of ecosystem services and estimating the } \\
\text { impact of land use and land cover change on regulating and cultural ecosystem services }\end{array}$ \\
\hline
\end{tabular}


erosion (Table 3). The approach of Dominati et al. (2014a) presented a natural capital/ES framework for ES valuation based on the bio-physical measures of many soil ES, estimated as flows by a dynamic model, and eventually valuated by commonly used economic techniques. Facing the limits for ES monetary valuation, these authors pointed that, although it provides only one perspective of the ES value, this approach gives more useful information to policy-makers than market prices might do.

\section{Soil ecosystem services and agricultural system sustainability}

Agricultural ecosystems offer newly recognized potential to deliver more diverse ES and to mitigate the level of "disservices", which is the term used for expressing losses of ES. Some agricultural practices, including reduced tillage or no-till, residue retention, permanent organic soil cover and crop rotations aim to increase crop yields by enhancing several regulating and supporting ES (Palm et al., 2014). Many of these services are interrelated and depend on a set of soil properties. However, establishing connections between specific soil properties and ecosystem processes is a hard task due to the inherent complexity of natural systems. According to Palm et al. (2007), the predictive relations between soil properties and soil processes are needed not only to understand natural systems but

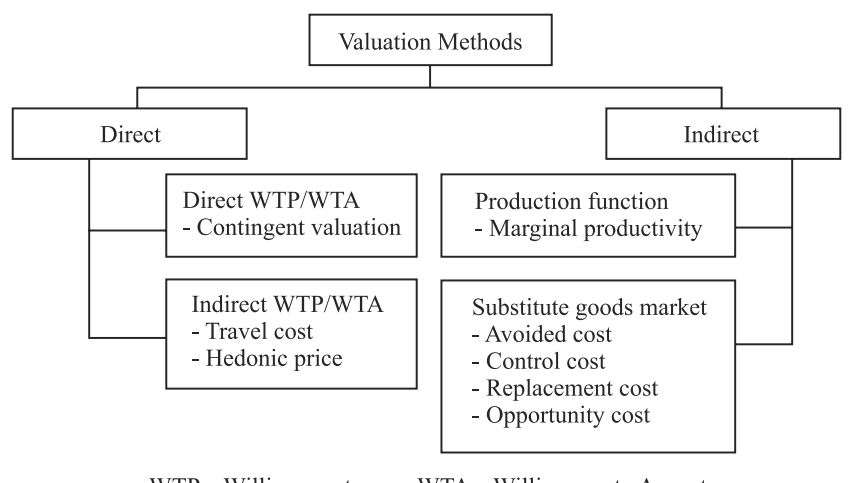

WTP - Willingness to pay; WTA - Willingness to Accept.

Figure 2. Economic valuation methods of ecosystem services. Source: Modified from Pearce \& Turner (1990), Ortiz (2003), Maia et al. (2004), Mueller (2007) and Mota et al. (2010). also to manage systems in order to favor rather than degrade ES.

In recent years, studies have been addressed to better characterize soil ES by understanding and quantifying soil functions and indicators according to field data from several farming systems in temperate and tropical regions (Rutgers et al., 2012; Williams \& Hedlund, 2013; Lavelle et al., 2014; Albizua et al., 2015; Parron et al., 2015). Moreover, scientists have advanced in mapping, modeling and valuating soil ES at regional or country scale, as well as developing tools to help agricultural and environmental policies (Wijnen et al., 2012; Dominati et al., 2014a, 2014b; Schulte et al., 2014; Calzolari et al., 2016). Table 4 presents the soil ES indicators used by these case studies.

These studies focused on specific ES, such as the soil's capacity to attenuate pollutants at country level (Wijnen et al., 2012), or addressed a set of ES and related functions (Dominati et al., 2014a; Calzolari et al., 2016).

The selection of soil ES indicators has been carried out using different approaches, depending on the assessment scale and data availability. Some studies used expertise consulting, such as the BPJ (Best Professional Judgment) method, applied in the Netherlands at local (Rutgers et al., 2012) and national scale (Wijnen et al., 2012). The selection of indicators was based on previous choice of ES assessed.

In order to quantify soil ES indicators, modeling tools have been developed to derive them either from available databases in national surveys and literature, or from field data collection. Dominati et al. (2014a, 2014b) used proxies, based on dynamic soil properties, to quantify ES (flows), using outputs from the SPASMO model. This approach offers a solution to apply ES concepts at various scales.

The studies based on field data from farming systems provided information on how soil management impacts its ES. For instance, Albizua et al. (2015) found that integrating ley into arable rotations can enhance the delivery of soil ES. From their studies in Colombian Llanos, Lavelle et al. (2014) pointed out that different farming systems may impact distinctly the various soil functions and related ES; e.g., macroinvertebrate diversity and soil macroaggregates had better scores in improved pastures, whilst indicators of carbon storage and greenhouse gas emissions reached better values in 
perennial crops (palm). They also highlighted the role of soil biota for the ES. Parron et al. (2015) assessed the effects of different farming systems on four selected soil services: carbon and nitrogen sequestration, nutrient cycling, water and soil conservation, and biodiversity conservation. Their results showed that some management practices were beneficial to some soil functions and services, while they damaged others. Dealing with such trade-offs and synergies, involving soil functions and services requires a priority analysis to decide on the goals for a given agroecosystem.

The tools to quantify soil services in progress can provide the assessment of the effects of policies on the ES supply and losses (Schulte et al., 2014), as well as

Table 3. Some valuation studies on soil ecosystem services (ES) provided by soil.

\begin{tabular}{lccc}
\hline Country & ES valuated & Valuation methods & Studies \\
\hline Brazil & Loss of nutrients & Replacement cost & Pugliesi et al. (2011) \\
New Zealand & Many ES & Market prices, replacement cost, defensive expenditure, provision cost & Dominati et al. (2014a) \\
Spain & Many ES & Contingent valuation & Colombo et al. (2006) \\
Tunisia & Soil retention & Production function & Kefi \& Yoshino (2010) \\
\hline World & Soil fertility & Meta-analysis & De Groot et al. (2012) \\
\hline
\end{tabular}

Table 4. Some case studies of soil ecosystem services (ES) approach applied to assess agricultural sustainability.

\begin{tabular}{|c|c|c|c|}
\hline Farming system & Soil ES indicators & References & Local \\
\hline The Netherlands' land use & $\begin{array}{l}\text { Functional microbial activity; potential carbon } \\
\text { mineralization rate; potential organic nitrogen } \\
\text { mineralization rate; soil organic matter, pH and } \\
\text { phosphorus content }\end{array}$ & Wijnen et al. (2012) & The Netherlands \\
\hline $\begin{array}{l}\text { Conventional, intensive and organic } \\
\text { farming practices with crop rotation } \\
\text { (potato, wheat, sugar beet and barley, } \\
\text { cauliflower, sprouts, carrots, parsnip, } \\
\text { onion, celeriac, rhubarb and corn) }\end{array}$ & $\begin{array}{l}\text { Soil organic matter, abundance and diversity of } \\
\text { earthworms, bacterial biomass, physiological diversity } \\
\text { of bacteria, } \mathrm{pH} \text {, diversity of nematodes, potential } \\
\text { C-mineralization, potential N-mineralization, diversity of } \\
\text { microarthropods, water soluble-P, extractable P, nematode } \\
\text { plant-parasites, metal concentrations }\end{array}$ & Rutgers et al. (2012) & $\begin{array}{l}\text { Polder Hoeksche } \\
\text { Waard (Rotterdam, } \\
\text { the Netherlands) }\end{array}$ \\
\hline $\begin{array}{l}\text { Conventional and organic crops on } \\
\text { arable barley fields }\end{array}$ & $\begin{array}{l}\text { Soil organic carbon, total nitrogen, hydro capacity, } \\
\text { phosphorus available, carbon storage, nutrient retention } \\
\text { and net } \mathrm{N} \text { mineralization }\end{array}$ & Williams \& Hedlund (2013) & Southern Sweden \\
\hline Sheep and beef & $\begin{array}{l}\text { Inherent and manageable soil properties used to calculate } \\
\text { flows (services) from soil natural capital stocks (model } \\
\text { SPASMO) }\end{array}$ & Dominati et al. (2014a) & $\begin{array}{l}\text { Waikato, New } \\
\text { Zealand }\end{array}$ \\
\hline $\begin{array}{l}\text { Sheep and beef pasture and spaced } \\
\text { planted trees as soil conservation } \\
\text { practice (soil recovery) }\end{array}$ & $\begin{array}{l}\mathrm{N} \text { fertilizer; native Olsen P; trace elements; bulk density; } \\
\text { slope; rainfall; potential P runoff; dung deposit; C stocks }\end{array}$ & Dominati et al. (2014b) & $\begin{array}{l}\text { East Coast of North } \\
\text { Island, New Zealand }\end{array}$ \\
\hline $\begin{array}{l}\text { Wheat with crop rotations, including } \\
\text { ley farming and manure; wheat } \\
\text { conventional farming }\end{array}$ & $\begin{array}{l}\text { Soil organic carbon, total } \mathrm{N} \text {, phosphorous, potassium, } \\
\mathrm{pH} \text {, water holding capacity, bacterial and fungal biomass, } \\
\text { grain yield and protein content }\end{array}$ & Albizua et al. (2015) & $\begin{array}{l}\text { Scania, southwest } \\
\text { Sweden. }\end{array}$ \\
\hline $\begin{array}{l}\text { Improved pasture, annual crops (rice, } \\
\text { corn, soybean and beans), palm oil } \\
\text { plantation, and original savannas }\end{array}$ & $\begin{array}{l}\text { Activity and diversity of macroinvertebrate communities, } \\
\text { soil chemical }(\mathrm{N}, \mathrm{P}, \mathrm{K}, \mathrm{Ca}, \mathrm{Mg}, \mathrm{Al}, \mathrm{C}) \text { and physical } \\
\text { indicators (macroaggregation, hydrological functions) }\end{array}$ & Lavelle et al. (2014) & $\begin{array}{l}\text { Orinoco River basin, } \\
\text { in eastern Colombia }\end{array}$ \\
\hline $\begin{array}{l}\text { Forests and grassland without } \\
\text { grazing, no-tillage and rotation crops } \\
\text { (integrated crop-livestock-forest, } \\
\text { integrated crop-livestock, no-tillage } \\
\text { crop), eucalyptus plantation and } \\
\text { native pasture }\end{array}$ & SOC and SON stocks & Parron et al. (2015) & $\begin{array}{l}\text { State of Paraná, } \\
\text { Brasil }\end{array}$ \\
\hline $\begin{array}{l}\text { Agriculture and environmental Irish } \\
\text { policies }\end{array}$ & $\begin{array}{l}\text { Denitrification capacity, } \mathrm{P} \text { adsorption, carbon } \\
\text { sequestration, area of high nature value, total quantity of } \\
\text { P in pig slurry }\end{array}$ & Schulte et al. (2014) & Ireland. \\
\hline $\begin{array}{l}\text { Grasslands and dairy farms, cereals } \\
\text { and pig, orchards, vineyards, } \\
\text { vegetables and cereals }\end{array}$ & $\begin{array}{l}\text { Potential habitat for soil organisms, bulk density, organic } \\
\mathrm{C} \text {, cation exchange capacity, } \mathrm{pH} \text {, rooting depth, soil } \\
\text { evaporation, potential carbon sequestration, potential land } \\
\text { capability map, soil bearing capacity, infiltration capacity, } \\
\text { water content at field capacity, presence of water table }\end{array}$ & Calzolari et al. (2016) & $\begin{array}{l}\text { Emilia Romagna, } \\
\text { Northern Italy }\end{array}$ \\
\hline
\end{tabular}


the valuation of the soil ES (Dominati et al., 2014a, 2014b).

Those studies presented the methods and showed the opportunities and the shortcomings of their application. Despite the need to advance in understanding the links between soil processes and the ES, some feasible management strategies are already well-known, and require putting the current knowledge into practice (Powlson et al., 2011).

\section{Challenges and opportunities for research and public policies related to agro-environmental sustainability and soil ecosystem services in Brazil}

There are many pressures that affect soil ecosystem services (Table 5). Although soil conservation was not considered a priority in government agendas in the past (Guerra et al., 2014), many agricultural production systems focusing on soil conservation have been developed and are being used in Brazil over recent decades. In commodity producing regions, some management systems have been rising in importance, such as no-tillage system (NTS), crop-livestock integrated system (CLIS) and croplivestock-forest integrated system (CLFIS) (Muniz et al., 2011; Assis et al., 2015), while in other regions, family farmers are also experiencing new integrated systems, such as organic farming and agroforestry (Martinelli et al., 2010). Evaluating the impact of these technologies on soil ES is required to subsidize decision-making and international agreements. However, there are many challenges ahead of scientific advances for supporting decisionmaking, as shown by Ferreira et al. (2012).

A major challenge is bringing scientists and decisionmakers together to develop public policies, and this has been considered a way to achieve practical results for agro-environmental sustainability (Daily et al., 2009; Stallman, 2011; Breure et al., 2012). Some global initiatives have improved integration of scientists and decision-makers, which have contributed to soil ES, such as: GESSOL Program (Breure et al., 2012); GEO's Biodiversity Observation Network (GEO BON), under the umbrella of GEOSS (the Global Earth Observation System of Systems) (Scholes et al., 2012); Global Soil Biodiversity Initiative (GSBI), under Global Soil Partnership (GSP) operated by FAO (Wall, 2013); Intergovernmental Platform on Biodiversity and Ecosystem Services, related to the Millennium Ecosystem Assessment and the Intergovernmental Panel on Climate Change (IPCC) (Díaz et al., 2015);

Table 5. Pressures that most affect soil ecosystem services, and related studies.

\begin{tabular}{|c|c|c|}
\hline Pressure & Soil ecosystem services & References \\
\hline Soil compaction & $\begin{array}{l}\text { Aeration; flow of water and nutrients; plant growth; water regulating; } \\
\text { water storage; food supply; erosion control }\end{array}$ & Reichert et al. (2007) \\
\hline Erosion processes & $\begin{array}{l}\text { Primary production; soil formation and renewal; nutrient cycling; } \\
\text { platform; refuge; water storage; food, fiber, fuel and wood } \\
\text { (biomaterials); mineral raw materials; biodiversity and genetic } \\
\text { resources; recycling and remediation activities; water quality and } \\
\text { quantity regulation; flood and drought control; erosion control; } \\
\text { recreation; aesthetic and heritage functions }\end{array}$ & $\begin{array}{l}\text { Minella et al. (2010), Lima \& Lopes (2011), } \\
\text { Guerra et al. (2014) }\end{array}$ \\
\hline Soil contamination & $\begin{array}{l}\text { Nutrient cycling; platform; refuge; food, fiber, fuel and wood } \\
\text { (biomaterials); biodiversity and genetic resources; recycling and } \\
\text { remediation activities; regulation of water quality; recreation }\end{array}$ & Dellamatrice \& Monteiro (2014) \\
\hline Carbon stock reduction & $\begin{array}{l}\text { Primary production; soil formation and renewal; nutrient cycling; } \\
\text { refuge; food, fiber, fuel and wood (biomaterials); biodiversity and } \\
\text { genetic resources; pathogen and disease control; GHG and climate } \\
\text { regulation }\end{array}$ & $\begin{array}{l}\text { Carvalho et al. (2010) Lima et al. (2012) } \\
\text { Madari et al. (2012), Coutinho et al. (2014), } \\
\text { Perrin et al. (2014) }\end{array}$ \\
\hline $\begin{array}{l}\text { Reduction of soil fertility and } \\
\text { biodiversity }\end{array}$ & $\begin{array}{l}\text { Primary production; soil formation and renewal; nutrient cycling; } \\
\text { refuge; food, fiber, fuel and wood (biomaterials); biodiversity and } \\
\text { genetic resources; pathogen and disease control; recycling and } \\
\text { remediation actions }\end{array}$ & Vezzani \& Mielniczuk (2009), Chaer (2010) \\
\hline $\begin{array}{l}\text { Vegetation fragmentation in the } \\
\text { landscape }\end{array}$ & $\begin{array}{l}\text { Primary production; soil formation and renewal; nutrient cycling; } \\
\text { refuge; water storage; mineral raw materials; biodiversity and genetic } \\
\text { resources; pathogen and disease control; water quality and quantity } \\
\text { regulation; flood and drought control; GHG and climate regulation; } \\
\text { erosion control; recreation; aesthetic and heritage function }\end{array}$ & Sparovek et al. (2010), Ferreira (2014) \\
\hline
\end{tabular}


Ecosystem Services Partnership (ESP) (Burkhard et al., 2010); and the Natural Capital (Kareiva et al., 2011).

This trend has also been observed in Brazil, where thematic research networks have worked to overcome those challenges, such as: Pecus (Oliveira, 2014); Fluxus (Madari et al., 2011); Environmental Services in Rural Landscape (Prado et al., 2015); Sustainable Amazon (Gardner et al., 2013); Soil Microbiology and Sustainability of Agricultural Systems (Mendes et al., 2011); and Biota FAPESP (Joly et al., 2010).

Regarding public policies for improving or maintaining ES provision, compensation for environmental services has been adopted as a conservation strategy worldwide (The Economics..., 2009). In Brazil, one type of compensation is the Payment for Environmental Services (PES), which has grown quickly (Pagiola et al., 2013), especially due to the incentive of the "Produtor de Água" (literal translation: water producer) program of the National Water Agency (local acronym: ANA) (Santos et al., 2010). The program has spread out around the country with the participation of several institutions, mainly the watershed committees and non-governmental organizations. The experiences of PES in Brazil are different from other PES in Latin America, as the Brazilian experience considers paying for agricultural conservation practices as an opportunity to improve and maintain soil ES, in addition to the reforestation and forest maintenance. Successful Latin-American experiences have been used as references for Brazilian PES (Calvache et al., 2012). The main challenges observed along the first decade of Brazilian experiences are: building the institutional arrangements, establishing the legal framework, maintaining the source to pay beneficiaries, and monitoring the effective PES impacts in ES (Pagiola et al., 2013; Young \& Bakker, 2015).

It is remarkable that changes in legal frameworks may create opportunities to improve PES. For instance, Leite (2014) pointed out that the Lei $\mathrm{n}^{\circ}$ 12.651/2012 (Brasil, 2012) - a Brazilian federal law - has opened a perspective of markets for ES. This law also established the Rural Environmental Registry (local acronym: CAR), which will allow the mapping of rural properties and the production of an environmental database - whose lack is a problem in Brazil - to support planning, management and compensation for soil ES (Cadastro..., 2015). Other public policies for environmental compensation were described by Mattos \& Hercowitz (2011), for example, the "Bolsa Floresta" and the Chico Mendes activism in the Amazon region; the Proambiente (a Brazilian program for social and environmental development of rural family production) and the ICMS Verde (a Brazilian tax on the circulation of goods and services).

The Brazilians' efforts towards reducing impacts on ES have been recognized at international forums. During the 15th UN Climate Change Conference of Parties (COP-15), the Brazilian government announced its commitment to reduce between 36.1 and $38.9 \%$ of GHG emissions by 2020. To achieve the goals related to the agricultural sector, the Sector Plan for Mitigation and Adaptation to Climate Change for the Consolidation of an Economy of Low Carbon in Agriculture (ABC Plan - in Portuguese, Plano ABC) was drawn up. The ABC Plan has a credit line, called the ABC Program, which provides credit for large farmers to finance the adoption of $\mathrm{ABC}$ conservationist technologies (Plano..., 2012). Although it does not have a specific focus on ES provision, it is important to promote discussion on this subject. There are other rural credit lines, mainly for small farmers, such as the Pronaf Eco, Pronaf Agroecologia (related to agroecology), Pronaf Floresta (related to forest); besides public policies on strengthening agroforestry systems (Porro \& Miccolis, 2011; Martins \& Ranieri, 2014). According to Grisa \& Schneider (2015), these programs are part of the third generation of public policies related to small farmers in Brazil, aimed at building markets with a focus on food security and sustainability.

However, public policies focused on soil conservation and ES provision, in Brazil, still face many challenges, such as the extent of degraded areas in the country, the socioeconomic and environmental particularities of each biome, and the lack of legal instruments, easily applicable indicators and a baseline to allow monitoring the effective impacts on ES provision. The governance is also a key issue related to the feasibility of public policies. According to Food and Agriculture Organization of The United Nations (FAO, 2014), responsible and effective governance mechanisms are required to reach sustainability in food and agriculture. Good governance shall enable policy, legal and institutional environments to "ensure accountability, equity, transparency and the rule of law" (FAO, 2014).

Pesq. agropec. bras., Brasília, v.51, n.9, p.1021-1038, set. 2016 DOI: 10.1590/S0100-204X2016000900002 
Another challenge related to public policies in Brazil is that they often are neither effective nor integrated strategies (Grisa \& Schneider, 2015). The ES approach can contribute to overcome such obstacles, as it is systemic and interdisciplinary, and involves suppliers and beneficiaries. In order to guide the use of ES approach by policy-makers, Wong et al. (2015) proposed a framework to bridge the gaps between concepts and methods in disciplines such as ecology, economy and politics, as well as to avoid the lack of data linking ecosystem metrics to final ES. The authors pointed that attention should be given to propose realistic targets, to acquire relevant data within the limits of time and resources, and to answer the needs of policy-makers. The task of developing strategies to public policies based on the ES approach must be considered also by soil scientists. They can contribute with valuable information and tools to improve the knowledge on soil management effects on ES, especially from agricultural practices.

\section{Final remarks}

Understanding soil functions has been a challenge and also the way to apply the soil ES approach. The methodological approach of soil quality indicators has greatly enhanced this comprehension, as it has been dealt with soil processes and their contribution to the ecosystem functions and services. Several research teams have developed integrated tools to assess, map, model and valuate ES, but only a couple of new modeling tools have considered the soil ecosystem services at different scales.

Some recent studies on soil ecosystem services in different countries have assessed impacts from farming systems, land use changes and management practices on soil functions and related-ES. They proved the importance of long-term field experiments to assess soil management practices in various agroecosystems, validating multiple soil ES indicators and developing models to estimate flows from soil ES stocks. The studies were carried out at several scales, and showed the opportunity for the interactions among farmers and other stakeholders to define soil ES targets, as well as the potential of ES assessment approaches to evaluate agricultural and environmental policies.
ES studies in Brazil have increased quickly, although soil is roughly considered. Advances in soil science are needed to better understand the effects of land use and management on soil ES.

For the soil ES approach to be effective, it must go beyond the action of scientists and policy-makers, and collaborate to the improvement of soil governance, which requires interdisciplinary view and engaged participation of stakeholders and policy-makers.

Interdisciplinary research efforts and resources should be applied to answer questions on ecosystem services related to: i) interactions between soil ES and management practices, as well as measurable indicators; ii) the design of societal-ecological system and its processes, to develop process-based models to quantify and valuate multiple ES and trade-offs; iii) comprehensive decision-making support tools; and iv) communication on ES to overcome discipline and cultural barriers.

\section{Acknowledgements}

To Livia Furriel de Castro, for the organization and standardization of references; to Thomas Lazarus Muello, for English review; and our colleague Heitor Luiz da Costa Coutinho (in memoriam) for being one of the pioneering researchers to study ES in Brazil. The authors thank him for the encouragement, enthusiasm, and spirit of inclusion and integration around this theme, which greatly contributed to its advance mainly at Embrapa Soils (one of Embrapa's units).

\section{References}

AITKENHEAD, M.J.; ALBANITO, F.; JONES, M.B.; BLACK, H.I.J. Development and testing of a process-based model (MOSES) for simulating soil processes, functions and ecosystem services. Ecological Modelling, v.222, p.3795-3810, 2011. DOI: 10.1016/j. ecolmodel.2011.09.014.

ALBIZUA, A.; WILLIANS, A.; HEDLUND, K.; PASCUAL, U. Crop rotations including ley and manure can promote ecosystem services in conventional farming systems. Applied Soil Ecology, v.95, p.54-61, 2015. DOI: 10.1016/j.apsoil.2015.06.003.

AN INTRODUCTORY guide to valuing ecosystems services. London: Department for Environment, Food and Rural Affairs, 2007. 65p.

ASSIS, P.C.R.; STONE, L.F.; MEDEIROS, J.C.; MADARI, B.E.; OLIVEIRA, J. de M.; WRUCK, F.J. Atributos físicos do solo em sistemas de integração lavoura-pecuária-floresta. Revista Brasileira de Engenharia Agrícola e Ambiental, v.19, p.309-316, 2015. DOI: 10.1590/1807-1929/agriambi.v19n4p309-316. 
AZIZ, I.; MAHMOOD, T.; ISLAM, K.R. Effect of long term no-till and conventional tillage practices on soil quality. Soil and Tillage Research, v.131, p.28-35, 2013. DOI: 10.1016/j.still.2013.03.002.

BARKMANN, J.; HELMING, K.; MÜLLER, K.; WIGGERING, $H$. Multifunctional landscapes: towards an analytical framework for sustainability assessment of agriculture and forestry in Europe. Müncheberg: Centre for Agricultural Landscape and Land Use Research, 2004. 422p.

BARRIOS, E. Soil biota, ecosystem services and land productivity. Ecological Economics, v.64, p.269-285, 2007. DOI: 10.1016/j. ecolecon.2007.03.004.

BARRIOS, E.; DELVE, R.J.; BEKUNDA, M.; MOWO, J.; AGUNDA, J.; RAMISCH, J.; TREJO, M.T.; THOMAS, R.J. Indicators of soil quality: a South-South development of a methodological guide for linking local and technical knowledge. Geoderma, v.135, p.248-259, 2006. DOI: 10.1016/j. geoderma.2005.12.007.

BEST, M.J.; PRYOR, M.; CLARK, D.B.; ROONEY, G.G.; ESSERY, R.L.H.; MÉNARD, C.B.; EDWARDS, J.M.; HENDRY, M.A.; PORSON, A.; GEDNEY, N.; MERCADO, L.M.; SITCH, S.; BLYTH, E.; BOUCHER, O.; COX, P.M.; GRIMMOND, C.S.B.; HARDING, R.J. The Joint UK Land Environment Simulator (JULES), model description. Part 1: energy and water fluxes. Geoscientific Model Development, v.4, p.677-699, 2011. DOI: 10.5194/gmd-4-677-2011.

BLUM, W.E.H. Functions of soil for society and the environment. Reviews in Environmental Science and Bio/Technology, v.4, p.75-79, 2005. DOI: 10.1007/s11157-005-2236-X.

BONDEAU, A.; SMITH, P.C.; ZAEHLE, S.; SCHAPHOFF, S.; LUCHT, W.; CRAMER, W.; GERTEN, D.; LOTZE-CAMPEN, H.; MÜLLER, C.; REICHSTEIN, M.; SMITH, B. Modelling the role of agriculture for the 20th century global terrestrial carbon balance. Global Change Biology, v.13, p.679-706, 2007. DOI: 10.1111/j.1365-2486.2006.01305.x.

BOUMA, J. Soil scientists in a changing world. Advances in Agronomy, v.88, p.67-96, 2005. DOI: 10.1016/S00652113(05)88003-4.

BOUMANS, R.; ROMAN, J.; ALTMAN, I.; KAUFMAN, L. The Multiscale Integrated Model of Ecosystem Services (MIMES): simulating the interactions of coupled human and natural systems. Ecosystem Services, v.12, p.30-41, 2015. DOI: $10.1016 / \mathrm{j}$. ecoser.2015.01.004.

BRADSHAW, R.H.W.; SYKES, M.T. Ecosystem dynamics: from the past to the future. Chichester: Wiley Blackwell, 2014. 336p.

BRASIL. Lei $n^{0} 12.651$, de 25 de maio de 2012. Dispõe sobre a proteção da vegetação nativa. Diário Oficial [da] República Federativa do Brasil, Brasília, DF, 28 maio 2012.

BREURE, A.M.; DEYN, G.B. de; DOMINATI, E.; EGLIN, T.; HEDLUND, K.; VAN ORSHOVEN, J.; POSTHUMA, L. Ecosystem services: a useful concept for soil policy making. Current Opinion in Environmental Sustainability, v.4, p.578585, 2012. DOI: 10.1016/j.cosust.2012.10.010.

BROEKX, S.; LIEKENS, I.; PEELAERTS, W.; DE NOCKER, L.; LANDUYT, D.; STAES, J.; MEIRE, P.; SCHAAFSMA, M.; VAN REETH, W.; VAN DEN KERCKHOVE, O.; CERULUS, T. A web application to support the quantification and valuation of ecosystem services. Environmental Impact Assessment Review, v.40, p.6574, 2013. DOI: 10.1016/j.eiar.2013.01.003.

BURKHARD, B.; CROSSMAN, N.; NEDKOV, S.; PETZ, K.; ALKEMADE, R. Mapping and modelling ecosystem services for science, policy and practice. Ecosystem Services, v.4, p.1-3, 2013. DOI: 10.1016/j.ecoser.2013.04.005.

BURKHARD, B.; PETROSILLO, I.; COSTANZA, R. Ecosystem services: bridging ecology, economy and social sciences. Ecological Complexity, v.7, p.257-259, 2010. DOI: 10.1016/j. ecocom.2010.07.001.

CADASTRO ambiental rural: nasce a identidade do imóvel rural. Curitiba: The Nature Conservancy, 2015. 143p.

CALVACHE, A.; BENÍTEZ, S.; RAMOS, A. Fondos de agua: conservando la infraestructura verde. Guía de diseño, creación y operación. Bogotá: The Nature Conservancy, Fundación FEMSA y Banco Interamericano de Desarrollo, 2012. 144p.

CALZOLARI, C.; UNGARO, F.; FILIPPI, N.; GUERMANDI, M.; MALUCELLI, F.; MARCHI, N.; STAFFILANI, F.; TAROCCO, P. A methodological framework to assess the multiple contributions of soils to ecosystem services delivery at regional scale. Geoderma, v.261, p.190-203, 2016. DOI: 10.1016/j.geoderma.2015.07.013.

CARDINALE, B.J.; DUFFY, J.E.; GONZALEZ, A.; HOOPER, D.U.; PERRINGS, C.; Venail, P.; NARWANI, A.; MACE, G.M.; TILMAN, D.; WARDLE, D.A.; KINZIG, A.P.; DAILY, G.C.; LOREAU, M.; GRACE, J.B.; LARINGAUDERIE, A.; SRIVASTAVA, D.S.; NAEEM, S. Biodiversity loss and its impact on humanity. Nature, v.486, p.59-67, 2012. DOI: 10.1038/ nature 11148 .

CARVALHO, J.L.N.; AVANZI, J.C.; SILVA, M.L.N.; MELLO, C.R. de; CERRI, C.E.P. Potencial de sequestro de carbono em diferentes biomas do Brasil. Revista Brasileira de Ciência do Solo, v.34, p.277-289, 2010. DOI: 10.1590/S0100-06832010000200001.

CHAER, G.M. Métodos de integração de indicadores para avaliação da qualidade do solo. In: PRADO, R.B.; TURETTA, A.P.; ANDRADE, A.G. de (Org.). Manejo e conservação do solo e da água no contexto das mudanças ambientais. Rio de Janeiro: Embrapa Solos, 2010. p.309-324.

CHAUDHARY, S.; MCGREGOR, A.; HOUSTON, D.; CHETTRI, $\mathrm{N}$. The evolution of ecosystem services: a time series and discoursecentered analysis. Environmental Science and Policy, v.54, p.2534, 2015. DOI: 10.1016/j.envsci.2015.04.025.

CHEN, J.; YU, Z.; OUYANG, J.; MENSVOORT, M.E.F. van. Factors affecting soil quality changes in the North China plain: a case study of Quzhou county. Agriculture Systems, v.91, p.171188, 2006. DOI: 10.1016/j.agsy.2006.02.005.

COLOMBO, S.; CALATRAVA-REQUENA, J.; HANLEY, N. Analysing the social benefits of soil conservation measures using stated preference methods. Ecological Economics, v.58, p.850861, 2006. DOI: 10.1016/j.ecolecon.2005.09.010.

COSTANZA, R.; D’ARGE, R.; DE GROOT, R.; FARBER, S.; GRASSO, M.; HANNON, B.; LIMBURG, K.; NAEEM, S.; O'NEILL, R.V.; PARUELO, J.; RASKIN, R.G.; SUTTON, P.; BELT, M. van den. The value of the world's ecosystem services 
and natural capital. Nature, v.387, p.253-260, 1997. DOI: $10.1038 / 387253 \mathrm{a} 0$.

COSTANZA, R.; GROOT, R. de; SUTTON, P.; PLOEG, S. van der; ANDERSON, S.J.; KUBISZEWSKI, I.; FARBER, S.; TURNER, R.K. Changes in the global value of ecosystem services. Global Environmental Change, v.26, p.152-158, 2014. DOI: 10.1016/j. gloenvcha.2014.04.002.

COSTANZA, R.; KUBISZEWSKI, I. The authorship structure of "ecosystem services" as a transdisciplinary field of scholarship. Ecosystem Services, v.1, p.16-25, 2012. DOI: 10.1016/j. ecoser.2012.06.002.

COSTANZA, R.; KUBISZEWSKI, I.; ERVIN, D.; BLUFFSTONE, R.; BOYD, J.; BROWN, D.; CHANG, H.; DUJON, V.; GRANEK, E.; POLASKY, S.; SHANDAS, V.; YEAKLEY, A. Valuing ecological systems and services. F1000 Reports Biology, v.3, p.16, 2011. DOI: 10.3410/B3-14.

COSTANZA, R.; QUATRINI, S.; ØYSTESE, S. Response to George Monbiot: the valuation of nature and ecosystem services is not privatization. 2012. Available at: $<\mathrm{http}: /$ goo.gl/xqtJLJ $>$. Accessed on: July 142015.

COUTINHO, H.L.C.; NOELLEMYER, E.; BALIEIRO, F. de C.; PINEIRO, G.; FIDALGO, E.C.C.; MARTIUS, C.; SILVA, C.F. da. Impacts of land-use change on carbon stocks and dynamics in Central-Southern South American biomes: Cerrado, Atlantic Forest and Southern Grasslands. In: BANWART, S.A.; NOELLEMEYER, E.; MILNE E. Soil carbon, science, management, and police for multiple benefits. Wallingford: CABI, 2014. p.243-265. (Scope series, 71). DOI: 10.1079/9781780645322.0243.

CROSSMAN, N.D.; BURKHARD, B.; NEDKOV, S.; WILLEMEN, L.; PETZ, K.; PALOMO, I.; DRAKOU, E.G.; MARTÍN-LOPEZ, B.; MCPHEARSON, T.; BOYANOVA, K.; ALKEMADE, R.; EGOH, B.; DUNBAR, M.B.; MAES, J. A blueprint for mapping and modelling ecosystem services. Ecosystem Services, v.4, p.414, 2013. DOI: 10.1016/j.ecoser.2013.02.001.

DAILY, G.C.; ALEXANDER, S.; EHRLICH, P.R.; GOULDER, L.; LUBCHENCO, J.; MATSON, P.A.; MOONEY, H.A.; POSTEL, S.; SCHNEIDER, S.H.; TILMAN, D.; WOODWELL, G.M. Ecosystem services: benefits supplied to human societies by natural ecosystems. Issues in Ecology, n.2, p.1-18, 1997.

DAILY, G.C.; POLASKY, S.; GOLDSTEIN, J.; KAREIVA, P.M.; MOONEY, H.A.; PEJCHAR, L.; RICKETTS, T.H.; SALZMAN, J.; SHALLENBERGER, R. Ecosystem services in decision making: time to deliver. Frontiers in Ecology and the Environment, v.7, p.21-28. 2009. DOI: 10.1890/080025.

DE GROOT, R.; BRANDER, L.; PLOEG, S. van der; COSTANZA, R.; BERNARD, F.; BRAAT, L.; CHRISTIE, M.; CROSSMAN, N.; GHERMANDI, A.; HEIN, L.; HUSSAIN, S.; KUMAR, P.; MCVITTIE, A.; PORTELA, R.; RODRIGUEZ, L.C.; BRINK, P. ten; BEUKERING, P. van. Global estimates of the value of ecosystems and their services in monetary units. Ecosystem Services, v.1, p.50-61, 2012. DOI: 10.1016/j.ecoser.2012.07.005.

DE GROOT, R.S.; WILSON, M.A.; BOUMANS, R.M.J. A typology for the classification, description and valuation of ecosystem functions, goods and services. Ecological Economics, v.41, p.393-408, 2002. DOI: 10.1016/S0921-8009(02)00089-7.
DELLAMATRICE, P.M.; MONTEIRO, R.T.R. Principais aspectos da poluição de rios brasileiros por pesticidas. Revista Brasileira de Engenharia Agrícola e Ambiental, v.18, p.1296-1301, 2014. DOI: 10.1590/1807-1929/agriambi.v18n12p1296-1301.

DÍAZ, S.; DEMISSEW, S.; CARABIAS, J.; JOLY, C.; LONSDALE, M.; ASH, N.; LARIGAUDERIE, A.; ADHIKARI, J.R.; ARICO, S.; BÁLDI, A.; BARTUSKA, A.; BASTE, I.A.; BILGIN, A.; BRONDIZIO, E.; CHAN, K.M.; FIGUEROA, V.E.; DURAIAPPAH, A.; FISCHER, M.; HILL, R.; KOETZ, T.; LEADLEY, P.; LYVER, P.; MACE, G.M.; MARTIN-LOPEZ, B.; OKUMURA, M.; PACHECO, D.; PASCUAL, U.; PÉREZ, E.S.; REYERS, B. The IPBES conceptual framework - connecting nature and people. Current Opinion in Environmental Sustainability, v.14, p.1-16, 2015. DOI: 10.1016/j.cosust.2014.11.002.

DOMINATI, E.; MACKAY, A.; GREEN, S.; PATTERSON, M. A soil change-based methodology for the quantification and valuation of ecosystem services from agroecosystems: A case study of pastoral agriculture in New Zealand. Ecological Economics, v.100, p.119-129, 2014a. DOI: 10.1016/j.ecolecon.2014.02.008.

DOMINATI, E.; PATTERSON, M.; MACKAY, A. A framework for classifying and quantifying the natural capital and ecosystem services of soils. Ecological Economics, v.69, p.1858-1868, 2010. DOI: 10.1016/j.ecolecon.2010.05.002.

DOMINATI, E.J.; MACKAY, A.; LYNCH, B.; HEATH, N.; MILLNER, I. An ecosystem services approach to the quantification of shallow mass movement erosion and the value of soil conservation practices. Ecosystem Services, v.9, p.204-215, 2014b. DOI: 10.1016/j.ecoser.2014.06.006.

DORAN, J.W.; PARKIN, T.B. Defining and assessing soil quality. In: DORAN, J.W.; COLEMAN, D.C.; BEZDICEK, D.F.; STEWART, B.A. (Ed.). Defining soil quality for a sustainable environment. Madison: Soil Science Society of America, 1994. p.3-21. (Special publication, 35). DOI: 10.2136/sssaspecpub35.c1.

DUMANSKI, J. Evolving concepts and opportunities in soil conservation. International Soil and Water Conservation Research, v.3, p.1-14, 2015. DOI: 10.1016/j.iswcr.2015.04.002.

ECOSYSTEM SERVICES PARTNERSHIP. ESP Working groups. Available at: <http://www.es-partnership.org/esp/79125/5/0/50>. Accessed on: Nov. 112015.

EGOH, B.; DRAKOU, E.G.; DUNBAR, M.B.; MAES, J.; WILLEMEN, L. Indicators for mapping ecosystem services: a review. Luxembourg: Publications Office of the European Union, 2012. 107p.

EUROPEAN COMMISSION. Thematic strategy for soil protection. 2006. Available at: <http://eur-lex.europa.eu/legalcontent/EN/TXT/?uri=URISERV:128181>. Accessed on: June 12 2015.

FERREIRA, J.; PARDINI, R.; METZGER, J.P.; FONSECA, C.R.; POMPEU, P.S.; SPAROVEK, G.; LOUZADA, J. Towards environmentally sustainable agriculture in Brazil: challenges and opportunities for applied ecological research. Journal of Applied Ecology, v.49, p.535-541, 2012. DOI: 10.1111/j.13652664.2012.02145.x.

FERREIRA, L.G.; SOUSA, S.B.; ARANTES, A.E. Radiografia das pastagens do Brasil. Goiânia: LAPIG/UFG, 2014. 214p. 
FIELD, J.P.; BRESHEARS, D.D.; LAW, D.J.; VILLEGAS, J.C.; LÓPEZ-HOFFMAN, L.; BROOKS, P.D.; CHOROVER, J.; BARRON-GAFFORD, G.A.; GALLERY, R.E.; LITVAK, M.E.; LYBRAND, R.A.; MCINTOSH, J.C.; MEIXNER, T.; NIU, G.-Y.; PAPUGA, S.A.; PELLETIER, J.D.; RASMUSSEN, C.R.; TROCH, P.A. Critical zone services: expanding context, constraints, and currency beyond ecosystem services. Vadose Zone Journal, v.14, p.2-7, 2015. DOI: 10.2136/vzj2014.10.0142.

FAO. FOOD AND AGRICULTURE ORGANIZATION OF THE UNITED NATIONS. Building a common vision for sustainable food and agriculture: principles and approaches. Rome: FAO, 2014. 50p.

GARDNER, T.A.; FERREIRA, J.; BARLOW, J.; LEES, A.C.; PARRY, L.; VIEIRA, I.C.G.; BERENGUER, E.; ABRAMOVAY, R.; ALEIXO, A.; ANDRETTI, C.; ARAGÃO, L.E.O.C.; ARAÚJO, I.; ÁVILA, W.S. de; BARDGETT, R.D.; BATISTELLA, M.; BEGOTTI, R.A.; BELDINI, T.; BLAS, D.E. de; BRAGA, R.F.; BRAGA, D. de L; BRITO, J.G. de; CAMARGO, P.B. de; SANTOS, F.C. dos; OLIVEIRA, V.C. de; CORDEIRO, A.C.N.; CARDOSO, T.M.; CARVALHO, D.R. de; CASTELANI, S.A.; CHAUL, J.C.M.; CERRI, C.E.; COSTA, F. de A.; COSTA, C.D.F. da; COUDEL, E.; COUTINHO, A.C.; CUNHA, D.; D’ANTONA, A.; DEZINCOURT, J.; DIAS-SILVA, K.; DURIGAN, M.; ESQUERDO, J.C.D.M.; FERES, J.; FERRAZ, S.F. de B.; FERREIRA, A.E. de M.; FIORINI, A.C.; SILVA, L.V.F. da; FRAZÃO, F.S.; GARRETT, R.; GOMES, A. dos S.; GONÇALVES, K. da S.; GUERRERO, J.B.; HAMADA, N.; HUGHES, R.M.; IGLIORI, D.C.; JESUS, E. da C.; JUEN, L.; JUNIOR, M.; OLIVEIRA JUNIOR, J.M.B. de; OLIVEIRA JUNIOR, R.C. de; SOUZA JUNIOR, C.; KAUFMANN, P.; KORASAKI, V.; LEAL, C.G.; LEITÃO, R.; LIMA, N.; ALMEIDA, M. de F.L.; LOURIVAL, R.; LOUZADA, J.; MAC NALLY, R.; MARCHAND, S.; MAUÉS, M.M.; MOREIRA, F.M.S.; MORSELLO, C.; MOURA, N.; NESSIMIAN, J.; NUNES, S.; OLIVEIRA, V.H.F.; PARDINI, R.; PEREIRA, H.C.; POMPEU, P.S.; RIBAS, C.R.; ROSSETTI, F.; SCHMIDT, F.A.; SILVA, R. da; SILVA, R.C.V.M. da; SILVA, T.F.M.R. da; SILVEIRA, J.; SIQUEIRA, J.V.; CARVALHO, T.S. de; SOLAR, R.R.C.; TANCREDI, N.S.H.; THOMSON, J.R.; TORRES, P.C.; VAZDE-MELLO, F.Z.; VEIGA, R.C.S.; VENTURIERI, A.; VIANA, C.; WEINHOLD, D.; ZANETTI, R.; ZUANON, J. A social and ecological assessment of tropical land uses at multiple scales: the Sustainable Amazon Network. Philosophical Transactions of the Royal Society B: Biological Sciences, v.368, p.1-11, 2013. DOI: 10.1098/rstb.2012.0166.

GREEN, S.R.; DIJSSEL, C. van den; SNOW, V.; CLOTHIER, B.E.; WEBB, T.; RUSSELL, J.; IRONSIDE, N.; DAVIDSON, P. SPASMO: a risk assessment model of water, nutrient and chemical fate under agricultural lands. In: CURRIE, L.D.; HANLY, J.A. (Ed.). Tools for nutrients and pollutant management: applications to agriculture and environmental quality. Palmerston North: Fertilizer and Lime Research Centre, Massey University, 2003. p.321-335.

GRISA, C.; SCHNEIDER, S. Políticas públicas de desenvolvimento rural no Brasil. Porto Alegre: Ed. da UFRGS, 2015. 624p.

GUERRA, A.J.T.; FULLEN, M.A.; JORGE, M. do C.O.; ALEXANDRE, S.T. Soil erosion and conservation in Brazil.
Anuário do Instituto de Geociências, v.37, p.81-91, 2014. DOI: 10.11137/2014_1_81_91.

HAINES-YOUNG, R.; POTSCHIN, M. The links between biodiversity, ecosystem services and human well-being. In: RAFAELLI, G.D.; FRID, C.L.J. (Ed.). Ecosystem ecology: a new synthesis. Cambridge: Cambridge University, 2010. p.110-139. DOI: $10.1017 / \mathrm{CBO} 9780511750458.007$.

HAYGARTH, P.; RITZ, K. The future of soils and land use in the UK: soil systems for the provision of land-based ecosystem services. Land Use Policy, v.26, p.187-197, 2009. Supplement 1. DOI: 10.1016/j.landusepol.2009.09.016.

HERMANN, A.; SCHLEIFER, S.; WRBKA, T. The concept of ecosystem services regarding landscape research: a review. Living Reviews in Landscape Research, v.5, p.1-37, 2011. DOI: 10.12942/lrlr-2011-1.

HERNÁNDEZ-MORCILLO, M.; PLIENINGER, T.; BIELING, C. An empirical review of cultural ecosystem service indicators. Ecological Indicators, v.29, p.434-444, 2013. DOI: 10.1016/j. ecolind.2013.01.013.

JENNY,H.Derivationofstatefactorequations of soilsandecosystems. Soil Science Society of America Proceedings, v.25, p.385-388, 1961. DOI: 10.2136/sssaj1961.03615995002500050023x.

JOLY, C.A.; RODRIGUES, R.R.; METZGER, J.P.; HADDAD, C.F.B.; VERDADE, L.M.; OLIVEIRA, M.C.; BOLZANI, V.S. Biodiversity conservation research, training, and policy in São Paulo. Science, v.328, p.1358-1359, 2010. DOI: 10.1126/ science.1188639.

KANDZIORA, M.; BURKHARD, B.; MÜLLER, F. Interactions of ecosystem properties, ecosystem integrity and ecosystem service indicators: a theoretical matrix exercise. Ecological Indicators, v.28, p.54-78, 2013. DOI: 10.1016/j.ecolind.2012.09.006.

KAREIVA, P.; TALLIS, H.; RICKETTS, T.H.; DAILY, G.C.; POLASKY, S. Natural capital: theory and practice of mapping ecosystem services. Oxford University Press, 2011. 432p. DOI: 10.1093/acprof:oso/9780199588992.001.0001.

KARLEN, D.L.; MAUSBACH, M.J.; DORAN, J.W.; CLINE, R.G.; HARRIS, R.F.; SCHUMAN, G.E. Soil quality: a concept, definition, and framework for evaluation (a guest editorial). Soil Science Society of America Journal, v.61, p.4-10, 1997. DOI: 10.2136/sssaj1997.03615995006100010001x.

KARLEN, D.L.; STOTT, D.E. A framework for evaluating physical and chemical indicators of soil quality. In: DORAN, J.W.; COLEMAN, D.C.; BEZDICEK, D.F.; STEWART, B.A. (Ed.). Defining soil quality for a sustainable environment. Madison: Soil Science Society of America, 1994. p.53-72. (Special publication, 35).

KEFI, M.; YOSHINO, K. Evaluation of the economic effects of soil erosion risk on agricultural productivity using remote sensing: case of watershed in Tunisia. International Archives of the Photogrammetry, Remote Sensing and Spatial Information Science, v.358, p.930-935, 2010.

LAL, R. Soil conservation and ecosystem services. International Soil and Water Conservation Research, v.2, p.36-47, 2014. DOI: 10.1016/S2095-6339(15)30021-6. 
LAVELLE, P.; RODRÍGUEZ, N.; ARGUELLO, O.; BERNAL, J.; BOTERO, C.; CHAPARRO, P.; GÓMEZ, Y.; GUTIÉRREZ, A.; HURTADO, M. del P.; LOAIZA, S.; PULLIDO, S.X.; RODRÍGUEZ, E.; SANABRIA, C.; VELÁSQUEZ, E.; FONTE, S.J. Soil ecosystem services and land use in the rapidly changing Orinoco River Basin of Colombia. Agriculture, Ecosystems and Environment, v.185, p.106-117, 2014. DOI: $10.1016 /$ j. agee.2013.12.020.

LEITE, J.F. O enredo da conservação no Estado de Goiás: possibilidades e desafios para a valorização do Cerrado em pé. 2014. 199p. Tese (Doutorado) - Universidade Federal de Goiás, Goiânia.

LIMA, J.E.F.W.; LOPES, W.T.A. Engenharia de sedimentos: na busca de soluções para problemas de erosão e assoreamento. Brasília: Associação Brasileira de Recursos Hídricos, 2011. 448p.

LIMA, M.A.; BODDEY, R.M.; ALVES, B.J.R.; MACHADO, P.L.O. de A.; URQUIAGA, S. (Ed.). Estoques de carbono e emissões de gases de efeito estufa na agropecuária brasileira. Brasília: Embrapa, 2012. 347p.

LIU, Z.; ZHOU, W.; LI, S.; HE, P.; LIANG, G.; LV, J.; JIN, H. Assessing soil quality of gleyed paddy soils with different productivities in subtropical China. Catena, v.133, p.293-302, 2015. DOI: 10.1016/j.catena.2015.05.029.

MADARI, B.E.; MAIA, C.M.B. de F.; NOVOTNY, E.H. Context and importance of biochar research. Pesquisa Agropecuária Brasileira, v.47, p.218-220, 2012. DOI: 10.1590/S0100204X2012000500001.

MADARI, B.E.; SALTON, J.C.; CARVALHO, A.M.; SCIVITTARO, W.B.; SANTOS, J.C.F.; OLIVEIRA JUNIOR, R.C.; TOSTO, S.G.; LEITE, L.F.C.; EVANGELISTA, S.R.M.; VICTORIA, D.C. Research project network: greenhouse gas emissions and carbon balance in crop production systems in Brazil (Fluxus). In: INTERNATIONAL WORKSHOP IN CLIMATE CHANGE AND AGRICUltURE, 2011, Campinas. Anais. Campinas: Embrapa Agricultural Informatics - Labex USA, 2011. p.19.

MAIA, A.G.; ROMEIRO, A.R.; REYDON, B.P. Valoração de recursos ambientais: metodologias e recomendações. Campinas: Instituto de Economia, Unicamp, 2004. (IE/Unicamp. Texto para discussão, 116).

MARTINELLI, L.A.; NAYLOR, R.; VITOUSEK, P.M.; MOUTINHO, P. Agriculture in Brazil: impacts, costs, and opportunities for a sustainable future. Current Opinion in Environmental Sustainability, v.2, p.431-438, 2010. DOI: 10.1016/j.cosust.2010.09.008.

MARTINÉZ-HARMS, M.J.; BALVANERA, P. Methods for mapping ecosystem service supply: a review. International Journal of Biodiversity Science, Ecosystem Services and Management, v.8, p.17-25, 2012. DOI: 10.1080/21513732.2012.663792.

MARTINS, T.P.; RANIERI, V.E.L. Agroforestry as an alternative to legal reserves. Ambiente and Sociedade, v.17, p.79-96, 2014. DOI: 10.1590/S1414-753X2014000300006.

MATTOS, L.M. de; HERCOWITZ, M. (Ed.). Economia do meio ambiente e serviços ambientais: estudo aplicado à agricultura familiar, às populações tradicionais e aos povos indígenas. Brasília:
Embrapa Informação Tecnológica; Planaltina: Embrapa Cerrados, 2011. 294p.

MCBRATNEY, A.; FIELD D.J.; KOCH, A. The dimensions of soil security. Geoderma, v.213, p.203-213, 2014. DOI: 10.1016/j. geoderma.2013.08.013.

MELE, P.M.; CROWLEY, D.E. Application of self-organizing maps for assessing soil biological quality. Agriculture, Ecosystems and Environment, v.126, p.139-152, 2008. DOI: 10.1016/j. agee.2007.12.008.

MENDES, I. de C.; REIS JUNIOR, F.B. dos; HUNGRIA, M.; FERNANDES, M.F.; CHAER, G.M.; MERCANTE, F.M.; ZILLI, J.E. Microbiologia do solo e sustentabilidade de sistemas agrícolas. In: FALEIRO, M.F.G.; ANDRADE, S.R.M. de; REIS JUNIOR, F.B. dos (Org.). Biotecnologia: estado da arte e aplicações na agropecuária. Planaltina: Embrapa Cerrados, 2011. p.219-244.

MILLENNIUM ECOSYSTEM ASSESSMENT. Ecosystems and human well-being: synthesis. Washington: Island Press, 2005. $155 \mathrm{p}$.

MINELLA, J.P.G.; MERTEN, G.H.; REICHERT, J.M.; CASSOL, E.A. Processos e modelagem da erosão: da parcela à bacia hidrográfica. In: PRADO, R B.; TURETTA, A.P.; ANDRADE, A.G. de (Org.). Manejo e conservação do solo e da água no contexto das mudanças ambientais. Rio de Janeiro: Embrapa Solos, 2010. p.105-135.

MONOKROUSOS, N.; PAPATHEODOROU, E.M.; DIAMANTOPOULOS, J.D.; STAMOU, G.P. Soil quality variables in organically and conventionally cultivated field sites. Soil Biology and Biochemistry, v.38, p.1282-1289, 2006. DOI: $10.1016 / \mathrm{j}$. soilbio.2005.09.023

MOTA, J.A.; BURSTZYN, M.; CANDIDO JUNIOR, J.O.; ORTIZ, R.A. A valoração da biodiversidade: conceitos e concepções metodológicas. In: MAY, P. (Org.). Economia do meio ambiente: teoria e prática. 2.ed. Rio de Janeiro: Elsevier, 2010. p.265-287.

MOTTA, R.S. da. Economia ambiental. Rio de Janeiro: FGV, 2006. 228p.

MUELLER, C.C. Os economistas e as relações entre o sistema econômico e o meio ambiente. Brasília: Ed. da UnB: Finatec, 2007. 562p.

MUNIZ, L.C.; MADARI, B.E.; TROVO, J.B. de F.; CANTANHÊDE, I.S. de L.; MACHADO, P.L.O. de A.; COBUCCI, T.; FRANÇA, A.F. de S. Soil biological attributes in pastures of different ages in a crop-livestock integrated system. Pesquisa Agropecuária Brasileira, v.46, p.1262-1268, 2011.

MURADIAN, R.; CORBERA, E.; PASCUAL, U.; KOSOY, N.; MAY,P.H. Reconciling theory and practice: an alternative conceptual framework for understanding payments for environmental services. Ecological Economics, v.69, p.1202-1208, 2010. DOI: 10.1016/j. ecolecon.2009.11.006.

NATIONAL RESEARCH COUNCIL. Basic research opportunities in earth science. Washington: National Academy of Sciences, 2001. 168p.

NATURAL CAPITAL PROJECT. Integrated valuation of ecosystem services and tradeoffs. Available at: $<$ http://www. 
naturalcapitalproject.org/InVEST.html>. Accessed on: July 10 2015.

NICHOLSON, E.; MACE, G.M.; ARMSWORTH, P.R.; ATKINSON, G.; BUCKLE, S.; CLEMENTS, T.; EWERS, R.M.; FA, J.E.; GARDNER, T.A.; GIBBONS, J.; GRENYER, R.; METCALFE, R.; MOURATO, S.; MUÛLS, M.; OSBORN, D.; REUMAN, D.C.; WATSON, C.; MILNER-GULLAND, E.J. Priority research areas for ecosystem services in a changing world. Journal of Applied Ecology, v.46, p.1365-2664, 2009. DOI: 10.1111/j.1365-2664.2009.01716.x.

OLIVEIRA, P.P.A. Protocolo para quantificação dos estoques de carbono do solo da rede de pesquisa Pecus. São Carlos: Embrapa Pecuária-Sudeste, 2014. 20p. (Embrapa Pecuária-Sudeste. Documentos, 116).

ORTIZ, R.A. Valoração econômica ambiental. In: MAY, P.H. (Org.). Economia do meio ambiente: teoria e prática. Rio de Janeiro: Campus, 2003. p.81-99.

PAGIOLA, S.; VON GLEHN, H.C.; TAFFARELLO, D. Experiências de pagamentos por serviços ambientais no Brasil. São Paulo: Secretaria do Meio Ambiente, 2013. 336p.

PALM, C.; BLANCO-CANQUI, H.; DECLERCK, F.; GATERE, L.; GRACE, P. Conservation agriculture and ecosystem services: An overview. Agriculture, Ecosystems and Environment, v.187, p.87-105, 2014. DOI: 10.1016/j.agee.2013.10.010.

PALM, C.; SANCHEZ, P.; AHAMED, S.; AWITI, A. Soils: a contemporary perspective. Annual Review of Environmental and Resources, v.32, p.99-129, 2007. DOI: 10.1146/annurev. energy.31.020105.100307.

PARISI, V.; MENTA, C.; GARDI, C.; JACOMINI, C.; MOZZANICA, E. Microarthropod communities as a tool to assess soil quality and biodiversity: a new approach in Italy. Agriculture, Ecosystems and Environment, v.105, p.323-333, 2005. DOI: 10.1016/j.agee.2004.02.002.

PARRON, L.M.; GARCIA, J.R.; OLIVEIRA, E.B. de; BROWN, G.G.; PRADO, R.B. Serviços ambientais em sistemas agrícolas e florestais do Bioma Mata Atlântica. Colombo: Embrapa Florestas; Brasília: Embrapa, 2015. 370p.

PAZ-KAGAN, T.; SHACHAK, M.; ZAADY, E.; KARNIELI, A. A spectral soil quality index (SSQI) for characterizing soil function in areas of changed land use. Geoderma, v.230-231, p.171-184, 2014. DOI: 10.1016/j.geoderma.2014.04.003.

PEARCE, D.W.; TURNER, R.K. Economics of natural resources and the environment. Baltimore: Johns Hopkins, 1990. 378p.

PEH, K.S.-H.; BALMFOR, A.; BRADBURY, R.B.; BROWN, C.; BUTCHART, S.H.M.; HUGHES, F.M.R.; STATTERSFIELD, A.; THOMAS, D.H.L.; WALPOLE, M.; BAYLISS, J.; GOWING, D.; JONES, J.P.G.; LEWIS, S.L.; MULLIGAN, M.; PANDEYA, B.; STRATFORD, C.; THOMPSON, J.R.; TURNER, K.; VIRA, B.; WILLCOCK, S.; BIRCH, J.C. TESSA: a toolkit for rapid assessment of ecosystem services at sites of biodiversity conservation importance. Ecosystem Services, v.5, p.51-57, 2013. DOI: 10.1016/j.ecoser.2013.06.003.

PERRIN, A.-S.; FUJISAKI, K. ; PETITJEAN, C.; SARRAZIN, M.; GODET, M.; GARRIC, B.; HORTH, J.-C.; BALBINO, L.C.; FILHO, A.S.; MACHADO, P.L.O. de A.; BROSSARD, M.
Conversion of forest to agriculture in Amazonia with the chop-andmulch method: Does it improve the soil carbon stock? Agriculture, Ecosystems and Environment, v.184, p.101-114, 2014. DOI: 10.1016/j.agee.2013.11.009.

PLANO setorial de mitigação e de adaptação às mudanças climáticas para a consolidação de uma economia de baixa emissão de carbono na agricultura: plano ABC (Agricultura de Baixa Emissão de Carbono). Brasília: Ministério da Agricultura, Pecuária e Abastecimento, 2012. 173p.

PLANNING for sustainable use of land resources: towards a new approach. In: SOMBROEK, W.G.; SIMS, D. (Ed.). Land and water bulletin. Rome: FAO, 1995. 60p. (FAO land and water bulletin, 2).

PORRO, R.; MICCOLIS, A. Políticas públicas para o desenvolvimento agroflorestal no Brasil. Belém: World Agroforestry Centre, 2011. 80p.

POWER, A.G. Ecosystem services and agriculture: tradeoffs and synergies. Philosophical Transactions of the Royal Society B: Biological Sciences, v.365, p.2959-2971, 2010. DOI: 10.1098/ rstb.2010.0143.

POWLSON, D.S.; GREGORY, P.J.; WHALLEY, W.R; QUINTON, J.N.; HOPKINS, D.W.; WHITMORE, A.P.; HIRSCH, P.R.; GOULDING, K.W.T. Soil management in relation to sustainable agriculture and ecosystem services. Food Policy, v.36, p.S72-S87, 2011. DOI: 10.1016/j.foodpol.2010.11.025.

PRADO, R.B.; FIDALGO, E.C.C.; FERREIRA, J.N.; CAMPANHA, M.M.; PARRON-VARGAS, L.M.; MATTOS, L.M.; PEDREIRA, B.C.C.G.; MONTEIRO, J.M.G.; TURETTA, A.P.D.; MARTINS, A.L.S.; DONA-GEMMA, G.K.; COUTINHO, H.L.C. Embrapa research network on ecosystem services in Brazil. In: Congreso Internacional de servícios ecosistémicos em los neotrópicos: de la investigación a la acción, 4, 2015, Mar Del Plata. De la investigación a la acción: libro de resúmenes. Mar del Plata: GEAP, 2015. 5p.

PUBLIESI, A.C.V.; MARINHO, M. de A.; MARQUES, J.F.; LUCARELLI, J.R.F. Valoração econômica do efeito da erosão em sistemas de manejo do solo empregando o método custo de reposição. Bragantia, v.70, 2011, p.113-121. DOI: 10.1590/S000687052011000100017.

PULLEMAN, M.; CREAMER, R.; HAMER, U.; HELDER, C.P.; PELOSI, C.; PÉRES, G.; RUTGERS, M. Soil biodiversity, biological indicators and soil ecosystem services: an overview of European approaches. Current Opinion in Environmental Sustainability, v.4, p.529-538, 2012. DOI: 10.1016/j.cosust.2012.10.009.

REICHERT, J.M.; SUZUKI, L.E.A.S.; REINERT, D.J. Compactação do solo em sistemas agropecuários e florestais: identificação, efeitos, limites críticos e mitigação. Tópicos em Ciência do Solo, v.5, p.49-134, 2007.

ROBINSON, D.A.; FRASER, I.; DOMINATI, E.J.; DAVÍĐSDÓTTIR, B.; JÓNSSON, J.O.G.; JONES, L.; JONES, S.B.; TULLER, M.; LEBRON, I.; BRISTOW, K.L.; SOUZA, D.M.; BANWART, S.; CLOTHIER, B.E. On the value of soil resources in the context of natural capital and ecosystem service delivery. Soil Science Society of America Journal, v.78, p.685-700, 2014. DOI: 10.2136/sssaj2014.01.0017. 
ROBINSON, D.A.; HOCKLEY, N.; DOMINATI, E.; LEBRON, I.; SCOW, K.M.; REYNOLDS, B.; EMMETT, B.A.; KEITH, A.M.; JONGE, L.W. DE; SCHJØNNING, P.; MOLDRUP, P.; JONES, S.B.; TULLER, M. Natural capital, ecosystem services, and soil change: why soil science must embrace an ecosystems approach. Vadose Zone Journal, v.11, 2012. DOI: 10.2136/vzj2011.0051.

ROMEIRO, A.R.; MAIA, A.G. Avaliação de custos e benefícios ambientais. Brasília: ENAP, 2011. 51p. (Cadernos Enap, 35).

ROUSSEAU, L.; FONTE, S.J.; TÉLLEZ, O.; VAN DER HOEK, R.; LAVELLE, P. Soil macrofauna as indicators of soil quality and land use impacts in smallholder agroecosystems of western Nicaragua. Ecological Indicators, v.27, p.71-82, 2013. DOI: 10.1016/j.ecolind.2012.11.020.

RUTGERS, M.; WIJNEN, H.J. van; SCHOUTEN, A.J.; MULDER, C.; KUITEN, A.M.P.; BRUSSAARD, L.; BREURE, A.M. A method to assess ecosystem services developed from soil attributes with stakeholders and data of four arable farms. Science of the Total Environment, v.415, p.39-48, 2012. DOI: 10.1016/j. scitotenv.2011.04.041.

SANTOS, D.G.; DOMINGUES, A.F.; GISLER, C.V.T. Gestão de recursos hídricos na agricultura: O Programa Produtor de Água. In: PRADO, R.B.; TURETTA, A.P.D.; ANDRADE, A.G. de (Org.). Manejo e conservação do solo e da água no contexto das mudanças ambientais. Rio de Janeiro: Embrapa Solos, 2010. p.353-376.

SCHOLES, R.J.; WALTERS, M.; TURAK, E.; SAARENMAA, H.; HEIP, C.H.R.; TUAMA, É.Ó.; FAITH, D.P.; MOONEY, H.A.; FERRIER, S.; JONGMAN, R.H.G.; HARRISON, I.J.; YAHARA, T.; PEREIRA, H.M.; LARIGAUDERIE, A.; GELLER, G. Building a global observing system for biodiversity. Current Opinion in Environmental Sustainability, v.4, p.139-146, 2012. DOI: 10.1016/j.cosust.2011.12.005.

SCHULTE, R.P.O.; CREAMER, R.E.; DONNELLAN, T.; FARRELLY, N.; FEALY, R.; O'DONOGHUE, C.; O'HUALLACHAIN, D. Functional land management: a framework for managing soil-based ecosystem services for the sustainable intensification of agriculture. Environmental Science and Policy, v.38, p.45-58, 2014. DOI: 10.1016/j.envsci.2013.10.002.

SHUKLA, M.K.; LAL, R.; EBINGER, M. Determining soil quality indicators by factor analysis. Soil and Tillage Research, v.87, p.194-204, 2006. DOI: 10.1016/j.still.2005.03.011.

SPAROVEK, G.; BERNDES, G.; KLUG, I.L.F.; BARRETTO, A.G.O.P. Brazilian agriculture and environmental legislation: status and future challenges. Environmental Science and Technology, v.44, p.6046-6053, 2010. DOI: 10.1021/es1007824.

STALLMAN, H.R. Ecosystem services in agriculture: determining suitability for provision by collective management. Ecological Economics, v.71, p.131-139, 2011. DOI: 10.1016/j. ecolecon.2011.08.016.

THE ECONOMICS OF ECOSYSTEMS AND BIODIVERSITY. The economics of ecosystems and biodiversity for national and international policy makers. Summary: responding to the value of nature. Wesseling: Welzel-Hardt, 2009. 48p.

TÓTH, G.; STOLBOVOY, V.; MONTANARELlA, L. Soil quality and sustainability evaluation: an integrated approach to support soil-related policies of the European Union. Luxembourg: Office for Official Publications of the European Communities, 2007. Available at: $<$ http://eusoils.jrc.ec.europa.eu/esdb_archive/ eusoils_docs/other/EUR22721.pdf $>$. Accessed on: July 122015.

VELASQUEZ, E.; LAVELLE, P.; ANDRADE, M. GISQ, a multifunctional indicator of soil quality. Soil Biology and Biochemistry, v.39, p.3066-3080, 2007. DOI: 10.1016/j. soilbio.2007.06.013.

VEZZANI, F.M.; MIELNICZUK, J. O solo como sistema. Curitiba: Edição dos Autores, 2011. 104p.

VEZZANI, F.M.; MIELNICZUK, J. Uma visão sobre qualidade do solo. Revista Brasileira de Ciência do Solo, v.33, p.743-755, 2009. DOI: 10.1590/S0100-06832009000400001.

VILLA, F.; BAGSTAD, K.J.; VOIGT, B.; JOHNSON, G.W; PORTELA, R.; HONZÁK, M.; BATKER, D. A methodology for adapTable and robust ecosystem services assessment. PLoS ONE, v.9, p.1-18, 2014. DOI: 10.1371/journal.pone.0091001.

WALL, D.H.; BARDGETT, R.D.; BEHAN-PELLETIER, V.; HERRICK, J.E.; JONES, T.H.; RITZ, K.; SIX, J.; STRONG, D.R.; VAN DER PUTTEN, W.H. Soil ecology and ecosystem services. Oxford: Oxford University Press, 2013. 546p.

WIJNEN, H.J. van; RUTGERS, M.; SCHOUTEN, A.J.; MULDER, C.; ZWART, D. de; BREURE, A.M. How to calculate the spatial distribution of ecosystem services - natural attenuation as example from The Netherlands. Science of the Total Environment, v.415, p.49-55, 2012. DOI: 10.1016/j.scitotenv.2011.05.058.

WILLEMEN, L.; BURKHARD, B.; CROSSMAN, N.; DRAKOU, E.G.; PALOMO, I. Editorial: best practices for mapping ecosystem services. Ecosystem Services, v.13, p.1-5, 2015. DOI: 10.1016/j. ecoser.2015.05.008.

WILLIAMS, A.; HEDLUND, K. Indicators of soil ecosystem services in conventional and organic arable fields along a gradient of landscape heterogeneity in southern Sweden. Applied Soil Ecology, v.65, p.1-7, 2013. DOI: 10.1016/j.apsoil.2012.12.019.

WONG, C.P.; JIANG, B.; KINZIG, A.P.; LEE, K.N.; OUYANG, Z. Linking ecosystem characteristics to final ecosystem services for public policy. Ecology Letters, v.18, p.108-118, 2015. DOI: 10.1111/ele.12389.

YEAR book 2012: emerging issues in our global environment. Nairobi: United Nations Environment Programme, 2012. 68p.

YOUNG, C.E.F.; BAKKER, L.B. de. Instrumentos econômicos e pagamentos por serviços ambientais no Brasil. In: INCENTIVOS econômicos para serviços ecossistêmicos no Brasil. Rio de Janeiro: Forest Trends, 2015. p.33-56.

Received on August 31, 2015 and accepted on November 26, 2015 